\title{
Characteristics and Sources of Selected Halocarbon and Hydrocarbon Volatile Organic Compounds in Surface Water of the Han River Basin
}

\author{
Jong Kwon Im ${ }^{1}$, Sujin Kim ${ }^{2} \oplus$, Young Seuk Kim ${ }^{1}$, Hye Ran Noh ${ }^{1}$, Young-Min Lee ${ }^{3, *}$ and Soon Ju Yu ${ }^{1, *}$ \\ 1 Han River Environment Research Center, National Institute of Environmental Research, 42, \\ Dumulmeori-gil 68beon-gil, Yangseo-myeon, Yangpyeong-gun 12585, Gyeonggi-do, Korea; \\ lim-jkjk@daum.net (J.K.I.); kys0522@korea.kr (Y.S.K.); anran1@korea.kr (H.R.N.) \\ 2 Center for Reservoir and Aquatic Systems Research, Department of Environmental Science, Baylor University, \\ Waco, TX 76798, USA; Sujin_Kim@baylor.edu \\ 3 Brain Korea for Sustainable Health \& Environment, Seoul National University, 1, Gwanak-ro, Gwanak-gu, \\ Seoul 08826, Korea \\ * Correspondence: ubyong@snu.ac.kr (Y.-M.L.); ysu1221@korea.kr (S.J.Y.); Tel.: +82-2-880-2810 (Y.-M.L.); \\ $+82-31-770-7240$ (S.J.Y.)
}

check for updates

Citation: Im, J.K.; Kim, S.; Kim, Y.S.; Noh, H.R.; Lee, Y.-M.; Yu, S.J.

Characteristics and Sources of

Selected Halocarbon and

Hydrocarbon Volatile Organic Compounds in Surface Water of the Han River Basin. Water 2021, 13, 2568. https://doi.org/10.3390/w13182568

Academic Editors: Lingzhan Miao and Jun Hou

Received: 6 August 2021

Accepted: 15 September 2021

Published: 17 September 2021

Publisher's Note: MDPI stays neutral with regard to jurisdictional claims in published maps and institutional affiliations.

Copyright: (c) 2021 by the authors. Licensee MDPI, Basel, Switzerland. This article is an open access article distributed under the terms and conditions of the Creative Commons Attribution (CC BY) license (https:// creativecommons.org/licenses/by/ $4.0 /)$.

\begin{abstract}
Volatile organic compounds (VOCs) are ubiquitous pollutants in surface water, which is the main source of drinking water in South Korea. We investigated the behavior (concentration, distribution, and environmental risk) of eleven selected VOCs in the surface water of the Han River tributaries using purge-and-trap gas chromatography/mass spectrometry. The average concentration of VOCs was $0.29 \pm 0.47 \mu \mathrm{g} / \mathrm{L}$. Chloroform and trichloroethylene (TCE) were the major pollutants, accounting for approximately $64.2 \%$ and $25.6 \%$ of the total concentration, respectively, and showing that halocarbons accounted for $94 \%$. Chloroform was positively correlated with TCE and xylenes, and TCE was positively correlated with tetrachloroethylene (PCE). No differences were observed in the temporal average concentrations of total VOCs, but the concentrations differed significantly among sub-watershed areas. The Imjin-Hantan River, Han River mainstream, and Anseong Stream watersheds had a high positive association with TCE, whereas the Bukhan and Namhan River watersheds had a strong positive link with chloroform. The contamination and detection frequency of VOCs were highest in industrial complexes, followed by urban and rural areas. Thus, point source pollution significantly contributed to VOC contamination of these tributaries. Risk quotients for most VOCs were $<1$, suggesting negligible risk. Considering the relatively high occurrence of VOCs and their potential ecological risks, continuous environmental monitoring and study of environmental impacts based on ecotoxicity studies of domestic aquatic species are warranted.
\end{abstract}

Keywords: chloroform; trichloroethylene; surface water; sewage treatment plant; wastewater treatment plant

\section{Introduction}

Pollution of aquatic ecosystems by anthropogenic chemicals is a major environmental problem worldwide [1,2]. Among these chemicals, volatile organic compounds (VOCs) are a major group of pollutants that are continuously introduced into aquatic ecosystems via natural and anthropogenic sources [3-5]. VOCs include various chemicals, some of which are hazardous to human health (e.g., carcinogens) [6] or the environment (e.g., photochemical smog) [7]. Some VOCs can be introduced into surface water systems through various sources, such as vehicle exhaust, gasoline vapor, paint, asphalt, industrial and residential coal burning, biomass burning, and petrochemical industries, thereby leading to ecosystem risks, even at low concentrations [8]. The toxic effects of drinking water contaminated with carcinogenic VOCs are central nervous system deficits, hematotoxicity, hepatic toxicity, renal toxicity, genotoxic effects, and chromosomal aberrations [9]. However, 
because VOCs evaporate easily, environmental investigations on VOCs have often focused on ambient air pollution [10].

In South Korea, the Ministry of Environment (MOE) has water quality standards (WQSs) in place to protect important drinking water resources in accordance with the Water Environment Conservation Act (Act No. 16605), while surface water quality is managed through periodic monitoring (MOE Notice No. 2018-6, Water Quality Standards in River Basins). Currently, a total of 20 chemicals, including nine VOCs, have been established in the Korean WQSs to protect public and ecosystem health. However, previous studies of VOCs in South Korea have primarily focused on air pollution problems [11-17], whereas studies of VOC contamination in surface water systems are insufficient [18].

Previous studies have reported the presence of VOCs in surface waters, rivers, groundwater, bottled water, and sewage treatment plants (STPs) and wastewater treatment plants (WWTPs) effluents worldwide, including in Greece [19], the United States [20,21], Taiwan [22], Spain [23], Russia [24], Italy [25,26], Kuwait [27], Israel [28], and China [29,30], ranging from tens of $\mathrm{ng} / \mathrm{L}$ to a few hundred ng/L. According to Cho et al. [18], regulated VOC concentrations in surface water in South Korea range from $10^{-5}$ to $10^{1} \mu \mathrm{g} / \mathrm{L}$. Although this prior study of VOCs in surface waters of the Han River basin was performed by Cho et al. [18], research on the impact of STPs and industrial WWTPs, as well as spatiotemporal variations in VOCs, is needed for an overall understanding of the Han River basin.

Various treatment technologies have been used to reduce the concentrations of VOCs in surface water; however, these technologies cannot completely treat STP and WWTP effluents [31,32]. Therefore, it is possible that the presence of residual VOCs in surface water may affect the aquatic ecosystem. To overcome this challenge, the sources of VOCs should be determined and managed through regular surveys of the tributaries in the Han River basin. In a recent study of the Han River basin, only seven out of the 17 observed VOCs were detected in surface water, with an estimated detection frequency of less than $6.0 \%$, except for cis-1,2-dichloroethene and 1,2-dichloropropane [33]. Apart from the 17 observed VOCs, further studies on the distribution of 13 unregulated VOCs were performed in October 2016 which showed that, excluding chloroform, less than $20 \%$ of the VOCs were detected [34]. The Ministry of Environment of Korea required further monitoring studies to accurately characterize the Han River basin and to establish VOC concentration standards in surface water. Therefore, additional assessments on VOC pollution sources and ecological risks in the Han River basin, and correlation between VOCs and their geographic associations, were conducted in this study to both supplement previous studies and provide preliminary data for effective policy making. The results can, thus, provide field-based data for widening the database of priority pollutants in order to conserve water quality in the Han River basin and will further be valuable for framing future legislation.

\section{Materials and Methods}

\subsection{Chemicals}

A total of 11 target analytes were studied, namely 1,1-dichloroethylene (1,1-DCE), 1,1,1-trichloroethane (1,1,1-TCA), bromoform, chloroform, naphthalene, styrene, tetrachloroethylene (PCE), toluene, trichloroethylene (TCE), vinyl chloride, and o-, $\mathrm{m-}$, and p-xylene. The physicochemical characteristics of these analytes are presented in Table S1. The 11 VOCs in this study are compounds that are not regulated by law in South Korea and are intended to be included in future regulations, and they were selected based on the results of research on the selection of priority management compounds for water quality and aquatic ecosystems [35]. The internal standard (IS) materials used for the analyses were fluorobenzene, 1,4-dichlorobenzene-d4, and chlorobenzene-d5. All analytical standards were purchased from AccuStandard (New Haven, CT, USA). Methanol of HPLC-grade was purchased from J.T. Baker (Pittsburgh, NJ, USA). Ultrapure deionized water was obtained from the Purelab DV35 water filtration system (ELGA LabWater, Buckinghamshire, UK). All reagents were of analytical grade, unless stated otherwise. 


\subsection{Study Area and Sample Collection}

The Han River basin, one of South Korea's four major river basins, has the largest area $\left(26,219 \mathrm{~km}^{2}\right)$ and the largest population $(3,004,897$ inhabitants in 2017) living in the riparian buffer zone of a river basin. In addition, the Han River basin includes Seoul, the capital and the largest metropolis in South Korea and one of the most densely populated cities worldwide $\left(16,728\right.$ person $/ \mathrm{km}^{2}$ in 2017). The sampling sites in the study area are shown in Figure 1. There were 36 sampling sites distributed across 5 sub-watersheds of the Han River basin. Of these, 7 were in the Namhan River watershed (N-1 to N-7), 5 were in the Bukhan River watershed (B-1 to B-5), 12 were in the Imjin-Hantan River watershed (IH-1 to $\mathrm{IH}-12), 8$ were in the Han River mainstream watershed (H-1 to $\mathrm{H}-8)$, and 4 were in the Anseong Stream watershed (A-1 to A-4). Potential sources of VOC contamination in the study area included 24 STPs and 7 industrial WWTPs. Information on the sampling sites and STP/WWTP locations are summarized in Table 1.

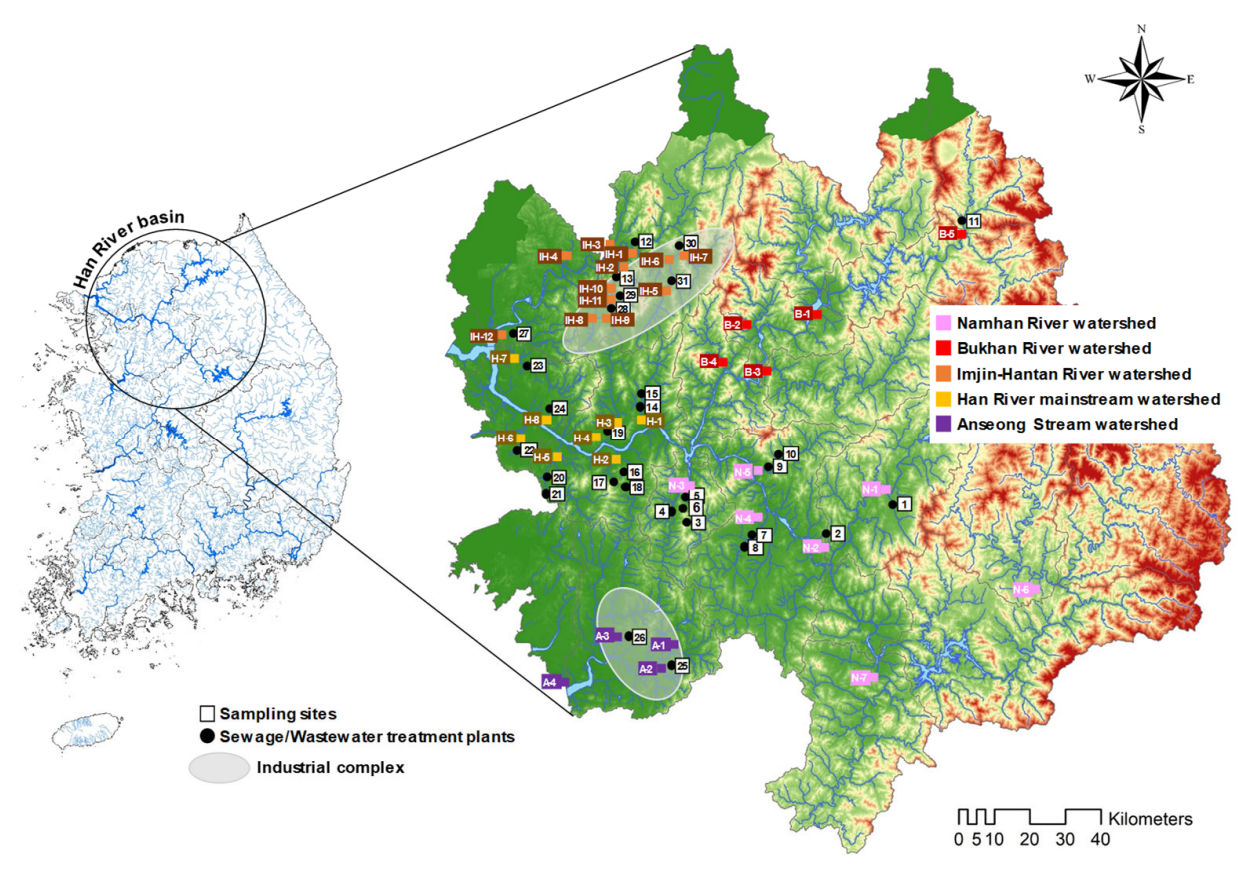

Figure 1. Location of sampling sites along tributaries of the Han River watershed.

Three sampling campaigns were conducted in April, June, and August of 2017. Surface water samples were collected in a Teflon bailer (1536-STDB-VT, ESS, CA, USA) and transferred to pre-cleaned $40 \mathrm{~mL}$ amber glass vials (with open-top screwcaps and Teflonlined septa) without headspace. All samples were collected in duplicate and stored in an ice box containing ice. Water quality parameters (water temperature, $\mathrm{pH}, \mathrm{DO}$, and conductivity) were measured using a YSI-556 MPS water quality meter (YSI Inc., Yellow Springs, OH, USA) during sampling, the results of which are presented in Table S2. The collected samples were analyzed within 4 days and stored at $4{ }^{\circ} \mathrm{C}$ until analysis.

\subsection{Analytical Procedure}

Before instrumental analysis, $50 \mu \mathrm{L}$ of an IS mixed solution $(0.2 \mu \mathrm{g} / \mathrm{mL}$ in methanol $)$ was added to each $40 \mathrm{~mL}$ sample. The VOCs in the water samples were analyzed using a Scion SQ 456- gas chromatography/mass spectrometry (GC/MS) system (Bruker, Billerica, MA, USA) equipped with an AQUATek 100 purge-and-trap (P\&T) autosampler (Teledyne Tekmar, Mason, OH, USA), according to method 524.2/8260 of the United States Environmental Protection Agency. Previous studies provide detailed descriptions of the P\&T-GC/MS conditions and selected ion monitoring (SIM) that were used for the identification of VOCs (Table S3) [33,34]. 
Table 1. Sampling site and point source information.

\begin{tabular}{|c|c|c|c|c|}
\hline \multirow{2}{*}{ Sub-Watershed } & \multirow{2}{*}{ Sites } & \multicolumn{2}{|l|}{ Location } & \multirow{2}{*}{$\begin{array}{c}\text { Related STP/WWTP }{ }^{(2)} \\
\left.\text { (Name, Discharge }\left(\mathrm{m}^{3} / \mathrm{d}\right)\right)\end{array}$} \\
\hline & & Longitude & Latitude & \\
\hline \multirow{7}{*}{$\begin{array}{l}\text { Namhan } \\
\text { River } \\
\text { (Rural) }\end{array}$} & $\mathrm{N}-1$ & $127^{\circ} 55^{\prime} 06.98^{\prime \prime}$ & $37^{\circ} 24^{\prime} 35.58^{\prime \prime}$ & 1(Wonju, 127,800$)$ \\
\hline & $\mathrm{N}-2$ & $127^{\circ} 45^{\prime} 07.95^{\prime \prime}$ & $37^{\circ} 14^{\prime} 11.08^{\prime \prime}$ & 2(Munmak, 5153) \\
\hline & N-3 & $127^{\circ} 18^{\prime} 46.51^{\prime \prime}$ & $37^{\circ} 25^{\prime} 19.79^{\prime \prime}$ & $\begin{array}{c}\text { 3(Gwangju, 24,177), 4(Konjiam, 21,415), } \\
\text { 5(Yangbeol 10 871) 6(Samri 4549) }\end{array}$ \\
\hline & $\mathrm{N}-4$ & $127^{\circ} 32^{\prime} 21.92^{\prime \prime}$ & $37^{\circ} 19^{\prime} 54.24^{\prime \prime}$ & 7(Icheon, 40,828), 8(Danwol, 1608) \\
\hline & $\mathrm{N}-5$ & $127^{\circ} 31^{\prime} 55.39^{\prime \prime}$ & $37^{\circ} 27^{\prime} 37.69^{\prime \prime}$ & 9(Yongmun, 2968), 10(Danwol, 1461) \\
\hline & N-6 & $128^{\circ} 27^{\prime} 35.38^{\prime \prime}$ & $37^{\circ} 09^{\prime} 56.03^{\prime \prime}$ & 0 \\
\hline & $\mathrm{N}-7$ & $127^{\circ} 53^{\prime} 59.44^{\prime \prime}$ & $36^{\circ} 26^{\prime} 29.43^{\prime \prime}$ & - \\
\hline \multirow{5}{*}{$\begin{array}{l}\text { Bukhan } \\
\text { River } \\
\text { (Rural) }\end{array}$} & B-1 & $127^{\circ} 42^{\prime} 49.94^{\prime \prime}$ & $37^{\circ} 52^{\prime} 12.22^{\prime \prime}$ & - \\
\hline & B-2 & $127^{\circ} 31^{\prime} 17.13^{\prime \prime}$ & $37^{\circ} 49^{\prime} 33.15^{\prime \prime}$ & - \\
\hline & B-3 & $127^{\circ} 35^{\prime} 34.94^{\prime \prime}$ & $37^{\circ} 43^{\prime} 12.09^{\prime \prime}$ & - \\
\hline & B-4 & $127^{\circ} 25^{\prime} 08.08^{\prime \prime}$ & $37^{\circ} 43^{\prime} 41.00^{\prime \prime}$ & - \\
\hline & B-5 & $128^{\circ} 11^{\prime} 13.69^{\prime \prime}$ & $38^{\circ} 04^{\prime} 58.72^{\prime \prime}$ & 11(Inje Bukmyeon, 1474) \\
\hline \multirow{12}{*}{$\begin{array}{l}\text { Imjin- } \\
\text { Hantan } \\
\text { River } \\
\text { (Rural) }\end{array}$} & IH-1 & $127^{\circ} 03^{\prime} 28.98^{\prime \prime}$ & $38^{\circ} 00^{\prime} 21.86^{\prime \prime}$ & 12(Cheongsan, 1198) \\
\hline & $\mathrm{IH}-2$ & $127^{\circ} 04^{\prime} 50.89^{\prime \prime}$ & $38^{\circ} 00^{\prime} 09.46^{\prime \prime}$ & 13(Dongducheon, 68,255 ) \\
\hline & $\mathrm{IH}-3$ & $127^{\circ} 02^{\prime} 06.78^{\prime \prime}$ & $38^{\circ} 03^{\prime} 12.79^{\prime \prime}$ & - \\
\hline & $\mathrm{IH}-4$ & $126^{\circ} 55^{\prime} 12.39^{\prime \prime}$ & $37^{\circ} 59^{\prime} 01.39^{\prime \prime}$ & - \\
\hline & $\mathrm{IH}-5$ & $127^{\circ} 14^{\prime} 38.56^{\prime \prime}$ & $37^{\circ} 57^{\prime} 55.80^{\prime \prime}$ & 31(Pocheon Jangja, 4999) (1) \\
\hline & IH-6 & $127^{\circ} 12^{\prime} 50.42^{\prime \prime}$ & $38^{\circ} 00^{\prime} 36.57^{\prime \prime}$ & -4 \\
\hline & IH-7 & $127^{\circ} 14^{\prime} 49.53^{\prime \prime}$ & $38^{\circ} 00^{\prime} 46.21^{\prime \prime}$ & 30(Pocheon Yangmun, 9728) ${ }^{(1)}$ \\
\hline & IH-8 & $127^{\circ} 01^{\prime} 19.19^{\prime \prime}$ & $37^{\circ} 52^{\prime} 09.34^{\prime \prime}$ & 28(Yangju Hongjuk, 456) ${ }^{(1)}$ \\
\hline & IH-9 & $126^{\circ} 59^{\prime} 51.92^{\prime \prime}$ & $37^{\circ} 52^{\prime} 16.13^{\prime \prime}$ & 28(Yangju Hongjuk, 456) ${ }^{(1)}$ \\
\hline & $\mathrm{IH}-10$ & $127^{\circ} 03^{\prime} 40.27^{\prime \prime}$ & $37^{\circ} 57^{\prime} 27.87^{\prime \prime}$ & 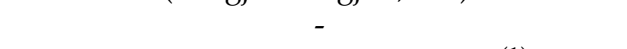 \\
\hline & $\mathrm{IH}-11$ & $127^{\circ} 03^{\prime} 31.84^{\prime \prime}$ & $37^{\circ} 56^{\prime} 48.70^{\prime \prime}$ & 29(Yangju Geomjun, 10,412) (1) \\
\hline & $\mathrm{IH}-12$ & $126^{\circ} 44^{\prime} 40.88^{\prime \prime}$ & $37^{\circ} 49^{\prime} 17.09^{\prime \prime}$ & 27(Paju LCD, 144,304) \\
\hline \multirow{8}{*}{$\begin{array}{c}\text { Han River } \\
\text { Mainstream } \\
\text { (Urban) }\end{array}$} & $\mathrm{H}-1$ & $127^{\circ} 10^{\prime} 04.98^{\prime \prime}$ & $37^{\circ} 34^{\prime} 58.67^{\prime \prime}$ & 14(Guri, 139,468), 15(Jingeon, 93,431) \\
\hline & $\mathrm{H}-2$ & $127^{\circ} 04^{\prime} 14.24^{\prime \prime}$ & $37^{\circ} 30^{\prime} 36.75^{\prime \prime}$ & $\begin{array}{c}\text { 16(Tancheon, 758,962),17(Gwacheon, 17,652), } \\
\text { 18(Seongnam, 365,638) }\end{array}$ \\
\hline & $\mathrm{H}-3$ & $127^{\circ} 03^{\prime} 19.63^{\prime \prime}$ & $37^{\circ} 32^{\prime} 57.56^{\prime \prime}$ & - \\
\hline & $\mathrm{H}-4$ & $127^{\circ} 02^{\prime} 51.73^{\prime \prime}$ & $37^{\circ} 32^{\prime} 51.76^{\prime \prime}$ & 19(Jungnang, 1,336,827) \\
\hline & $\mathrm{H}-5$ & $126^{\circ} 52^{\prime} 51.39^{\prime \prime}$ & $37^{\circ} 32^{\prime} 52.21^{\prime \prime}$ & $\begin{array}{c}\text { 20(Anyang Bakdal, 162,013), 21(Seoksu, } \\
190,983 \text { ) }\end{array}$ \\
\hline & H-6 & $126^{\circ} 46^{\prime} 37.24^{\prime \prime}$ & $37^{\circ} 34^{\prime} 10.39^{\prime \prime}$ & 22(Gulpo, 700,772) \\
\hline & $\mathrm{H}-7$ & $126^{\circ} 44^{\prime} 18.74^{\prime \prime}$ & $37^{\circ} 45^{\prime} 05.37^{\prime \prime}$ & 23(Geumchon, 24,522) \\
\hline & $\mathrm{H}-8$ & $126^{\circ} 50^{\prime} 06.88^{\prime \prime}$ & $37^{\circ} 35^{\prime} 35.59^{\prime \prime}$ & 24(Samsong, 7910) \\
\hline \multirow{4}{*}{$\begin{array}{l}\text { Anseong } \\
\text { Stream } \\
\text { (Rural) }\end{array}$} & A-1 & $127^{\circ} 14^{\prime} 23.35^{\prime \prime}$ & $37^{\circ} 00^{\prime} 21.68^{\prime \prime}$ & - \\
\hline & A-2 & $127^{\circ} 11^{\prime} 23.02^{\prime \prime}$ & $36^{\circ} 58^{\prime} 31.44^{\prime \prime}$ & 25(Pyeongtaek Songtan, 7283) ${ }^{(1)}$ \\
\hline & A-3 & $127^{\circ} 04^{\prime} 15.07^{\prime \prime}$ & $37^{\circ} 01^{\prime} 48.60^{\prime \prime}$ & 26(Anseong 2nd, 3845) ${ }^{(1)}$ \\
\hline & A-4 & $126^{\circ} 58^{\prime} 51.08^{\prime \prime}$ & $36^{\circ} 56^{\prime} 56.01^{\prime \prime}$ & - \\
\hline
\end{tabular}

${ }^{(1)}$ industrial complex, ${ }^{(2)}$ source: South Korea Ministry of Environment, 2017 sewerage statistics and 2017 operation status of wastewater treatment plants.

\subsection{Quality Assurance/Quality Control (QA/QC)}

Spike-and-recovery and linearity-of-dilution experiments were performed to validate and assess the accuracy of the VOC analyses. The QA/QC samples were processed in the same manner as the field samples. Recoveries of the spiked test samples ranged from 89 to $118 \%$, and the relative standard deviation (RSD) was less than $10 \%$. All calibration curves exhibited good linearity $\left(R^{2}>0.99\right)$. The method detection limit (MDL) was calculated as follows [36]: MDL = standard deviation of seven replicate measurements $(\mathrm{s}) \times \mathrm{Stu}-$ dent's $t$-test value with six degrees of freedom (3.143). The MDL ranged from 0.005 to $0.012 \mu \mathrm{g} / \mathrm{L}$ [33]. VOCs were not detected in the solvent blanks or procedural blanks. All glassware was rinsed with methanol prior to use to remove any organic contaminants. 


\subsection{Calculation of Ecological Risk}

For the VOCs detected in at least one of the water sampling sites, risk quotients (RQs) were determined by calculating the quotient between the maximum measured environmental concentration (MEC) and the predicted no-effect concentration (PNEC). An $R Q$ value $>1$ indicates a potential ecological risk. Toxicity data for the target VOCs were obtained from the US Environmental Protection Agency (EPA) ECOTOX database (http://cfpub.epa.gov/ecotox). Data for freshwater algae, crustaceans, and fish with measurements of chemical analysis and ecologically relevant endpoints for mortality, growth, reproduction, population, and ecosystem were selected. The PNEC values were derived based on the assessment factor (AF) by following the technical guidance of the European Commission, which has been published previously [34].

\subsection{Data Analyses}

A Spearman correlation analysis, analysis of variance (ANOVA), and a principal component analysis (PCA) were conducted using the IBM SPSS Statistics 25 software package (SPSS Inc., Chicago, IL, USA). The statistical significance was set at $p<0.05$. The PCA was used to describe the similarities and differences between the studied subwatersheds with respect to the major VOCs. Detection frequency (\%) was calculated as the number of samples above MDL/total samples $\times 100$.

\section{Results and Discussion}

\subsection{Overall Distribution of VOC Concentrations}

Figure 2 shows the VOC concentrations in the tributaries of the Han River basin (see Table S4 for details). Except for naphthalene and vinyl chloride, all of the target VOCs were detected at least once. The concentrations of VOCs ranged from 0 (not detected) to $2.66 \mu \mathrm{g} / \mathrm{L}$, with an average concentration of total VOCs of $0.29 \mu \mathrm{g} / \mathrm{L}$. Chloroform and TCE accounted for $89.9 \%$ of the total detected VOCs (i.e., the sum of individual VOCs).

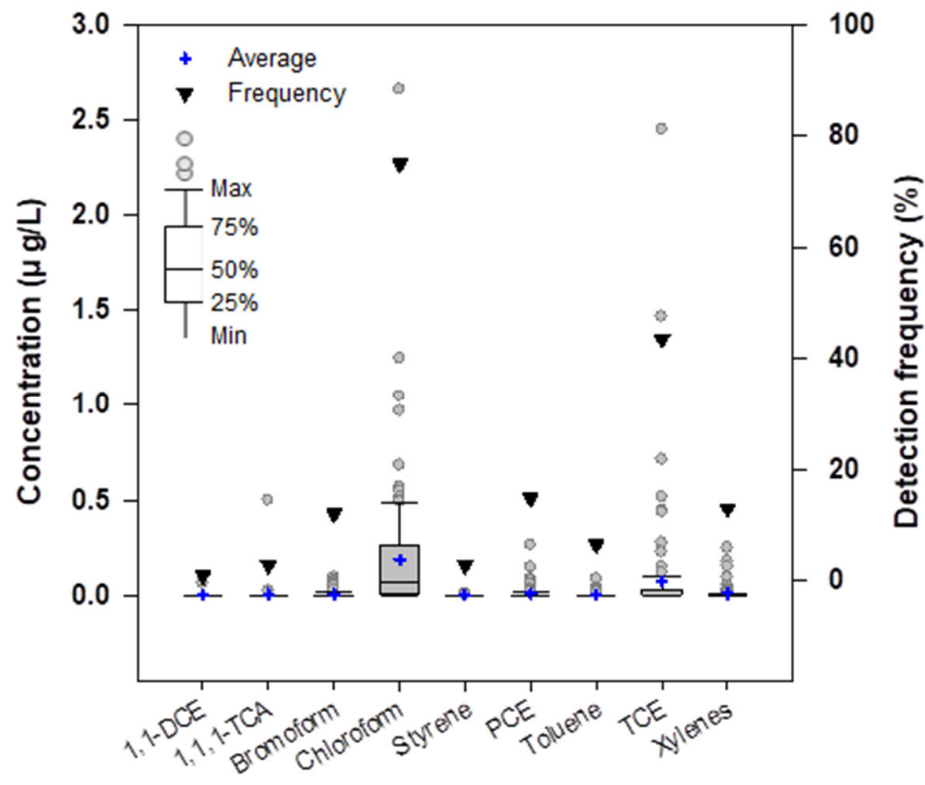

Figure 2. Distributions of VOC concentrations. Xylenes include $\mathrm{m}-, \mathrm{o}^{-}$, and $\mathrm{p}$ - isomers of xylene; undetected naphthalene and vinyl chloride were excluded; sample size $(n)=108$.

The dominant VOC was chloroform, with an average concentration of $0.19 \mu \mathrm{g} / \mathrm{L}$, accounting for $64.2 \%$ of the total VOCs detected. This chloroform concentration was significantly lower than the South Korean water quality standard of $80 \mu \mathrm{g} / \mathrm{L}$ (MOE Notice No. 2018-6) (Table S5) [34]. However, the maximum chloroform concentration $(2.66 \mu \mathrm{g} / \mathrm{L})$ 
exceeded the EU annual average environmental quality standard of $2.5 \mu \mathrm{g} / \mathrm{L}$ (Directive $2013 / 39 / E U)$. Chloroform also exhibited the highest detection frequency of $75.0 \%$. Chloroform was once widely used as a solvent, but its use has decreased due to safety and environmental concerns, especially because it is classified as a Group 2B substance (possibly carcinogenic to humans; IARC (1999). Nevertheless, chloroform is still an important industrial chemical. Chloroform is mainly used in the preparation of chlorodifluoromethane (HCFC-22; ATSDR (1997). HCFC-22, also called R-22 or Freon, is commonly used as a propellant and refrigerant. Chloroform can also be generated in small amounts in chlorinated water as a disinfection byproduct [37]. In addition, chloroform dissolves easily and has high mobility in water (log Kow < 2) (see Table S1). Therefore, chloroform can be transported over long distances in water and is likely to be found extensively in surface waters. Another study covering a similar time period reported that the average and maximum concentrations of chloroform in Dongjiang Lake, China, were 0.22 and $0.28 \mu \mathrm{g} / \mathrm{L}$, respectively, with a detection frequency of 100\% [6]. In Poyang Lake in China, the average and maximum chloroform concentrations were 0.19 and $1.38 \mu \mathrm{g} / \mathrm{L}$, respectively, with a detection frequency of $100 \%$ [38]. Based on these results, we concluded that the most frequently observed VOC concentrations in this study are similar to those observed in China.

The average concentration of TCE, the second most dominant VOC, was $0.08 \mu \mathrm{g} / \mathrm{L}$, accounting for $25.6 \%$ of the total VOCs detected. The average TCE concentration was also significantly lower than the South Korean drinking water quality standard of $30 \mu \mathrm{g} / \mathrm{L}$ (MOE Decree No. 833) (Table S5) [34]. TCE was the second most frequently detected VOC, with a detection frequency of $43.5 \%$. TCE, which is classified as a Group 1 substance (carcinogenic to humans; [39]), is mainly used as a solvent for metal degreasing in the automotive and metal industries. TCE is also used to make 1,1,1,2-tetrafluoroethane (HFC134a; [40]). HFC-134a (or R-134a) is used as a refrigerant in household refrigerators and automobile air conditioners as a replacement for R-12. TCE breaks down very slowly in water and is removed mostly through evaporation [41]. Therefore, TCE is one of the most common chlorine compounds detected in groundwater pollution. Compared to another study during a similar period, the average and maximum concentrations of TCE in Poyang Lake, China were 0.006 and $0.008 \mu \mathrm{g} / \mathrm{L}$, respectively, with a detection frequency of $18 \%$ [38].

Other VOC concentrations ranged from not detected to $0.008 \mu \mathrm{g} / \mathrm{L}$, accounting for $11.1 \%$ of the total, with detection frequencies below $13.9 \%$. Overall, the results of the sample analyses were similar to or lower than the results obtained by other studies of river and surface waters $[18,19,23]$. The present study is the first to report that 1,1-DCE and $1,1,-\mathrm{TCE}$ have low detection frequencies; however, the non-detection of vinyl chloride is consistent with previous studies [34]. Some VOCs with detection frequencies of more than $10 \%$ exhibited correlations with each other, i.e., bromoform, chloroform, PCE, TCE, and xylenes (Table 2). Chloroform had a positive correlation with TCE and xylenes $(\rho=0.252$ and 0.208 , respectively), and TCE had a positive correlation with PCE $(\rho=0.620)$ and a negative correlation with bromoform $(\rho=-0.212)$ [13].

Table 2. Spearman's correlation coefficients between the detected VOCs $(n=108)$.

\begin{tabular}{lccccccccc}
\hline & 1,1-DCE & $\mathbf{1 , 1 , 1 - T C A}$ & Bromoform & Chloroform & Styrene & PCE & Toluene & TCE & Xylenes \\
\hline 1,1-DCE & 1.000 & $0.583^{* *}$ & -0.036 & -0.067 & -0.016 & $0.233^{*}$ & -0.025 & 0.180 & -0.037 \\
\hline 1,1,1-TCA & & 1.000 & 0.107 & 0.054 & -0.029 & $0.272^{* *}$ & -0.044 & $0.281^{* *}$ & -0.065 \\
\hline Bromoform & & & 1.000 & 0.011 & 0.100 & -0.153 & 0.133 & $-0.212^{*}$ & -0.044 \\
\hline Chloroform & & & 1.000 & 0.162 & -0.024 & 0.096 & $0.252^{* *}$ & $0.208^{*}$ \\
\hline Styrene & & & & & 1.000 & -0.070 & $0.405^{* *}$ & -0.141 & 0.122 \\
\hline
\end{tabular}


Table 2. Cont.

\begin{tabular}{|c|c|c|c|c|c|c|c|c|}
\hline & 1,1-DCE & 1,1,1-TCA & Bromoform Chloroform & Styrene & PCE & Toluene & TCE & Xylenes \\
\hline PCE & & & & & 1.000 & -0.109 & $0.620 * *$ & -0.014 \\
\hline Toluene & & & & & & 1.000 & -0.137 & -0.003 \\
\hline TCE & & & & & & & 1.000 & 0.106 \\
\hline Xylenes & & & & & & & & 1.000 \\
\hline
\end{tabular}

* Correlation is significant at the 0.05 level (both sides). ${ }^{* *}$ Correlation is significant at the 0.01 level (both sides).

\subsection{Spatiotemporal Distributions of VOCs}

Figure 3a shows the distributions of VOC concentrations during the different sampling periods. The average total concentration of VOCs was $0.35 \mu \mathrm{g} / \mathrm{L}$ in April (i.e., early spring), $0.24 \mu \mathrm{g} / \mathrm{L}$ in June (i.e., early summer), and $0.28 \mu \mathrm{g} / \mathrm{L}$ in August (i.e., late summer). Statistically, the concentrations of most VOCs were found to be similar at each sampling time and site $(p>0.05)$, but the concentration of some VOCs differed for different sampling times (bromoform, chloroform, and TCE, $p<0.05$ ) and sampling sites (bromoform, PCE, and xylenes, $p<0.05$ ) (Table S6). However, the temporal concentrations of chloroform and TCE, the major VOCs detected, were the opposite of each other. This occurred because chloroform and TCE exhibited their highest concentrations at site IH-9 in April and site $\mathrm{IH}-2$ in August, respectively. This indicates that the lack of significant temporal variations in total VOCs could be attributed to a continuous complementary inflow of major VOCs. In general, low VOC concentrations occur in relatively high water temperatures during the summer, due to the depletion of VOCs by photochemical degradation in the atmosphere $[11,42,43]$. In contrast, due to low water temperatures and increased use of fossil fuels, VOCs exhibit relatively high concentrations during the winter [11,44]. However, temporally different concentrations may also occur depending on the source characteristics of the VOCs $[5,44,45]$.

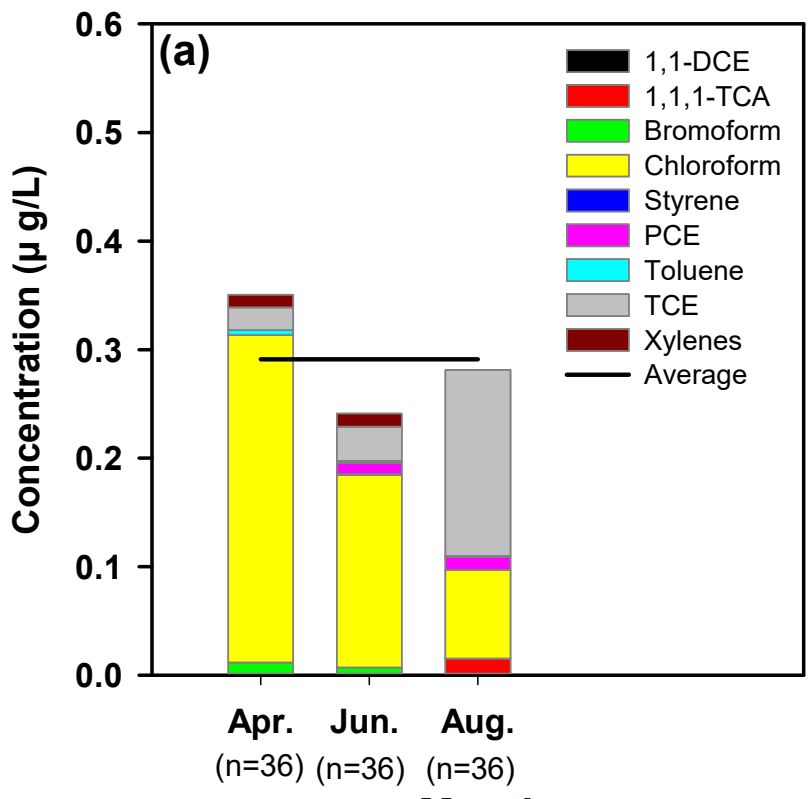

Month

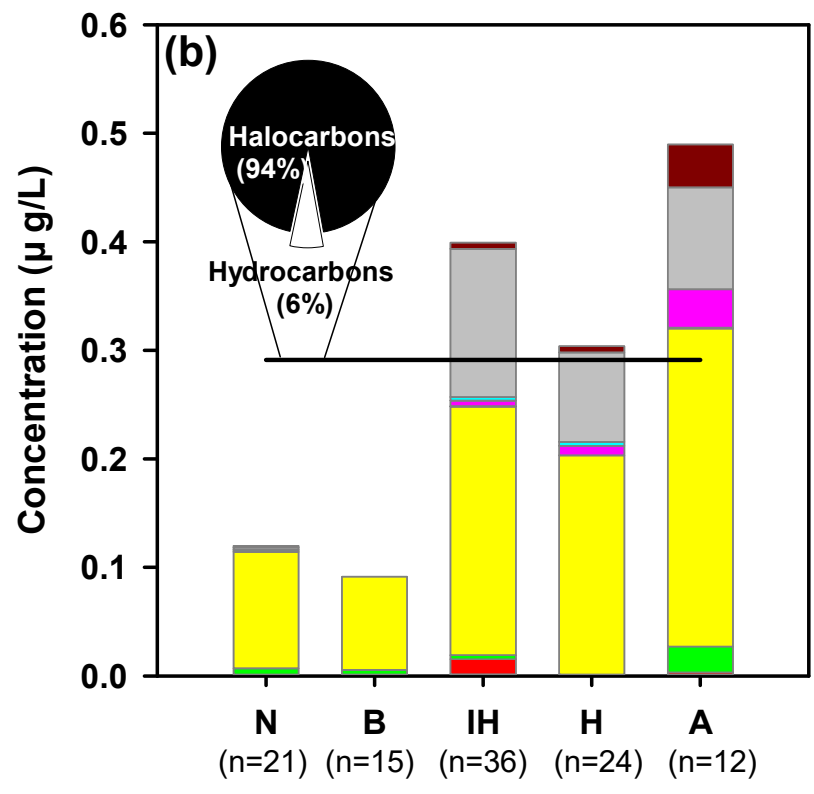

Sub-watershed

Figure 3. (a) Temporal and (b) spatial variations in VOC concentrations. Xylenes include m-, o-, and p-isomers of xylene; undetected naphthalene and vinyl chloride were excluded. N: Namhan River; B: Bukhan River; IH: Imjin-Hantan River; H: Han River mainstream; A: Anseong Stream. 
Figures $3 \mathrm{~b}$ and $\mathrm{S} 1$ show the distributions of VOC concentrations in different subwatersheds of the Han River basin. The average total VOC concentrations were 0.12, 0.09, $0.40,0.30$, and $0.49 \mu \mathrm{g} / \mathrm{L}$ in the Namhan River, Bukhan River, Imjin-Hantan River, Han River mainstream, and Anseong Stream watersheds, respectively. The VOC concentrations of the Namhan and Bukhan River watersheds and the other three watersheds were significantly different $(p<0.05)$. This can be attributed to the capacity and number of WWTPs, which are potential sources of contamination.

PCA was performed on the VOC concentration data according to the sites of the sampling month. PCA is a common multivariate statistical approach used to determine the relationships among several interrelated variables, wherein the variables with comparable properties are grouped into a same principal component (PC) [12,46,47]. Therefore, PCA is a useful method for the interpretation of chemical trends in water bodies and groundwater [48,49]. Four VOCs having a detection frequency of $10 \%$ or more (chloroform, PCE, TCE, and xylenes) were selected as the variables. As shown in the PCA results (Figure 4) based on the relationship between the target VOCs and the sites, PC1 and PC2 contributed to $33.99 \%$ and $32.75 \%$ of the total variance, respectively. Chloroform and xylenes exhibited strong positive loads on PC1, which in turn had a strong positive correlation with IHR-9, NHR-3, and NHR-4. PCE and TCE exhibited strong positive loads on PC2, which in turn had a strong positive correlation with AS-3, HR-4, HR-5, IHR-2, and IHR-8.

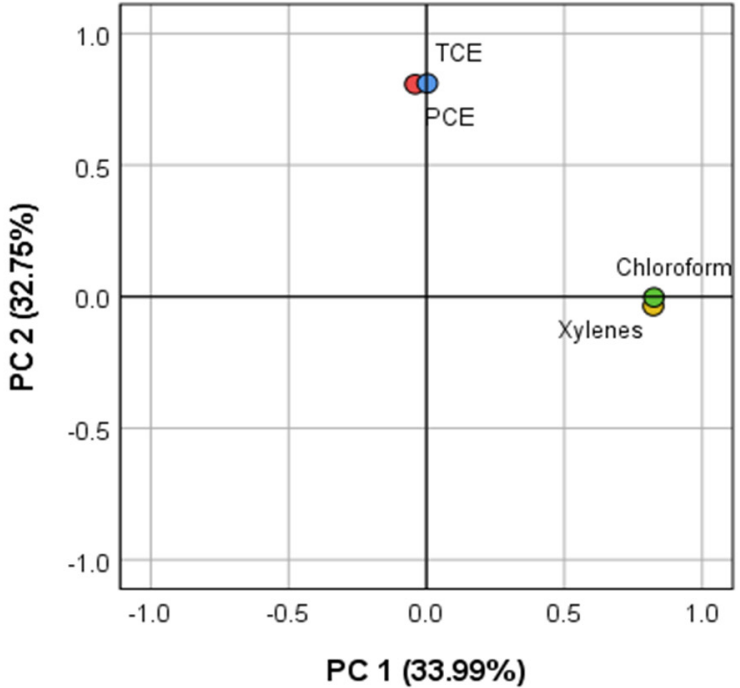

(a)

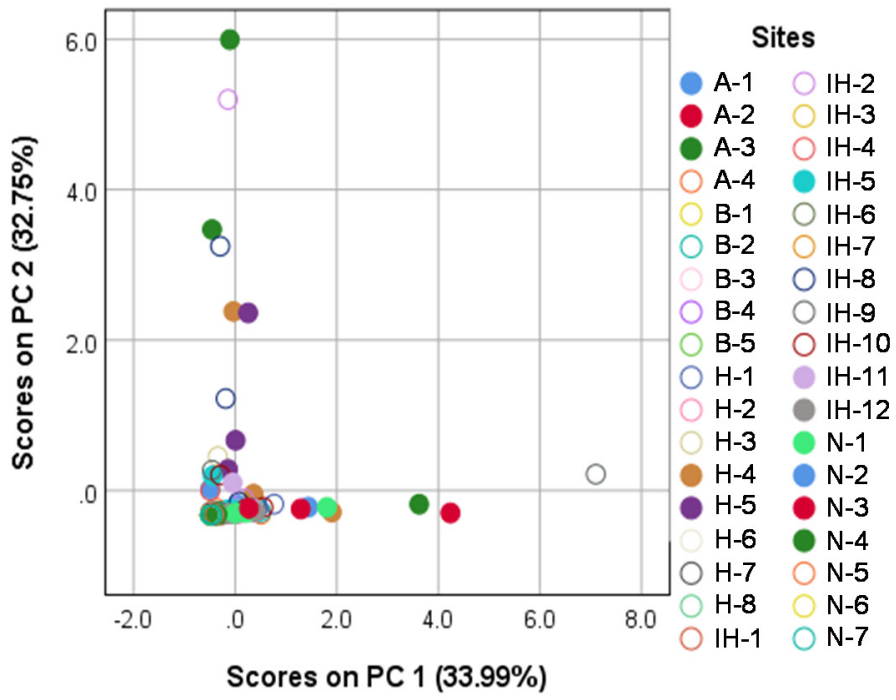

(b)

Figure 4. (a) Loading plot and (b) scores plot of the PCA. Xylenes include m-, o-, and p- isomers of xylene; N: Namhan River; B: Bukhan River; IH: Imjin-Hantan River; H: Han River mainstream; A: Anseong Stream.

Halocarbons (i.e., halogenated VOCs) accounted for $94 \%$ of the total VOCs due to the compositions of the major VOC types. The composition ratio of the halocarbon VOCs was similar in almost all of the sub-watersheds. In the Anseong Stream watershed, the composition ratio of hydrocarbon VOCs was relatively high (15\%). In addition, PCE, which is a solvent widely used in dry cleaning, was detected only in the Imjin-Hantan River, Han River mainstream, and Anseong Stream watersheds. There are industrial complexes located in the Imjin-Hantan River and Anseong Stream watershed areas, and the Han River mainstream watershed is one the most urbanized areas in South Korea. In other countries, studies measuring VOCs in aquatic environments have primarily investigated urban and industrial sources that exhibited relatively higher VOC concentrations than rural areas $[19,22,23,50,51]$. Therefore, the differences in the VOC concentrations among the sub-watershed areas are potentially related to the sources of the halocarbons. 


\subsection{Potential VOC Sources}

Figure 5 shows the average concentrations of VOCs at each sampling site. The VOCs in the Han River basin were likely associated with STP and industrial WWTP discharge, as the average total concentration of VOCs is generally high downstream of STPs and industrial WWTPs. The discharge from STP-1, $-14,-16$, and -19 was relatively higher than that of other STPs in the same watershed (see Table 1), which might have contributed to increased VOC concentrations at sites $\mathrm{N}-1, \mathrm{H}-1, \mathrm{H}-2$, and $\mathrm{H}-4$.

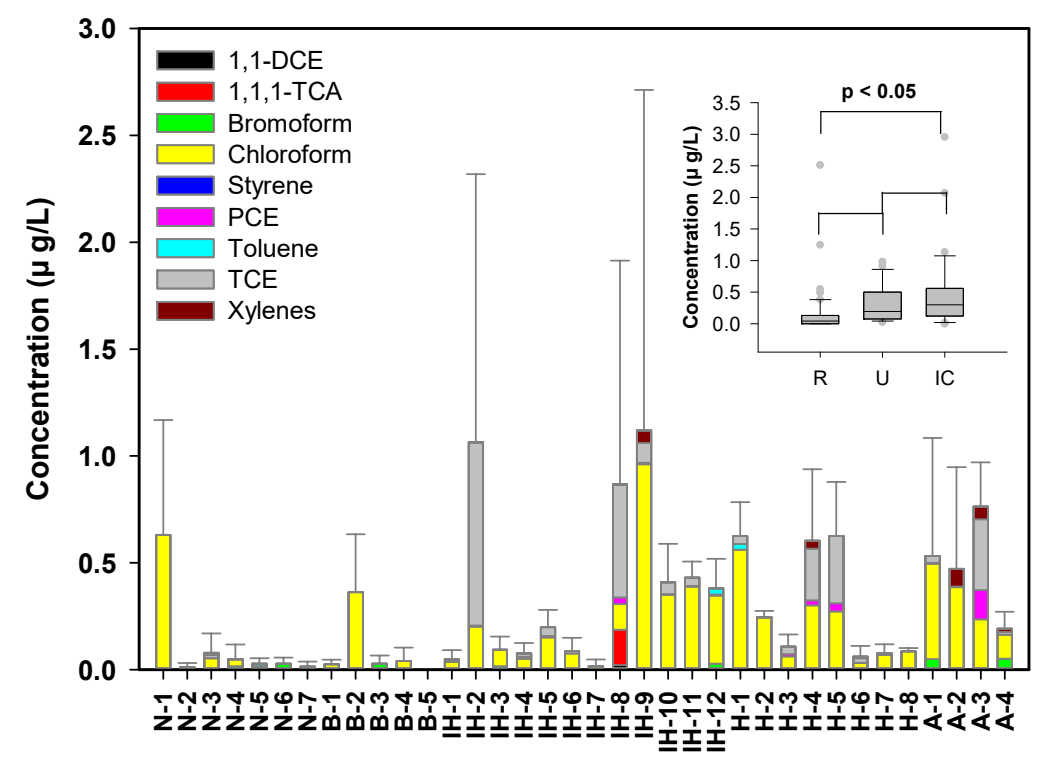

Sampling sites

Figure 5. Distributions of VOC concentrations. Xylenes include $\mathrm{m-}, \mathrm{o}^{-}$, and $\mathrm{p}$ - isomers of xylene; undetected naphthalene and vinyl chloride were excluded; sample size $(n)=108$.

The VOC concentrations from rural, urban, and industrial areas were significantly different $(p<0.05)$, with average total VOC concentrations of $0.16,0.30$, and $0.48 \mu \mathrm{g} / \mathrm{L}$, respectively. In the industrial areas, the high VOC concentrations at sites IH-5 to IH-9, $\mathrm{IH}-12, \mathrm{~A}-2$, and A-3 can be attributed to industrial effluent (i.e., WWTPs 25-31). In addition, STP 13 also handles industrial wastewater, which might affect the VOC concentrations at sites IH-10 and IH-11, indicating that the main source of the VOCs could be point discharge sources. These results are similar to those observed in other studies in Korea and other countries [24].

The major sources of VOCs, from the results of this study, could be considered to be STPs and WWTPs, which are mostly point discharge sources. This is similar to the findings of the previous study on 17 VOCs [33]. These results could be attributed to the characteristics of pollutant discharge of the Han River water system rather than to VOC properties. Previous research on pollutant sources of VOCs mainly dealt with point and non-point sources $[4,18,29,31,32,43,45,52]$. Particularly, STPs and WWTPs are not designed to remove specific pollutants; hence, complete removal is not possible $[31,32,43,45]$. In addition, during heavy rainfall, surface water may directly flow into nearby rivers, without treatment [53]. However, since non-point sources are uncontrolled and present an unpredictable source of pollution, special management and continuous investigation are required in this regard [52]. The results of this study can be inferred from the distribution of VOCs in surface water by point sources; however, the effect of non-point sources should not be overlooked. Therefore, it is necessary to consider future research strategies. 


\subsection{Ecological Risk of VOCs}

Most of the VOCs analyzed in this study had RQ values less than 1 (calculated using the maximum MECs observed during each sampling period), implying that the direct impact of the current occurrence was negligible in the Han River basin (Figure 6). Only one compound, toluene, had an $R Q>1$, in April $(R Q=1.47)$, which suggests a potential ecological risk of this VOC during the spring season. The RQ values for toluene during other sampling periods were 0.489 in June and 0.388 in August, relatively higher than those of the other VOCs, which ranged from 0.000135 to 0.163 . However, this result should be interpreted with caution for the following reasons. First, we used toxicological data collected from the US EPA ECOTOX database based on international standard species, not domestic species from Korea, due to a lack of relevant ecotoxicity studies. For example, fathead minnow (Pimephales promelas), rainbow trout (Oncorhynchus mykiss), and zebrafish (Danio rerio) are the generally recommended fish species for internationally standardized tests; however, they are not native to South Korea. The applicability of domestic aquatic species (e.g., the fish Oryzias latipes and the crustacean Moina macrocopa) for standardized toxicity tests is unclear, and only limited toxicity data from such species are available currently [54]. Therefore, the actual risk might be different for Korean aquatic species and the environment. Additionally, in terms of the ecological risk of toluene, at sampling point A-4, which had the highest toluene concentration with an RQ value above 1 in April, toluene was not detected in June or August, which indicates large temporal variations. Similar to our findings, in a previous risk assessment conducted with water samples collected from the same river in 2010 [18], the RQ values of most of the target VOCs, including 1,1-DCE and bromoform, were less than 1, while toluene was not analyzed. In contrast, in a previous study, the RQ of toluene was greater than 1 consistently, but the value (1.2) was low [34].

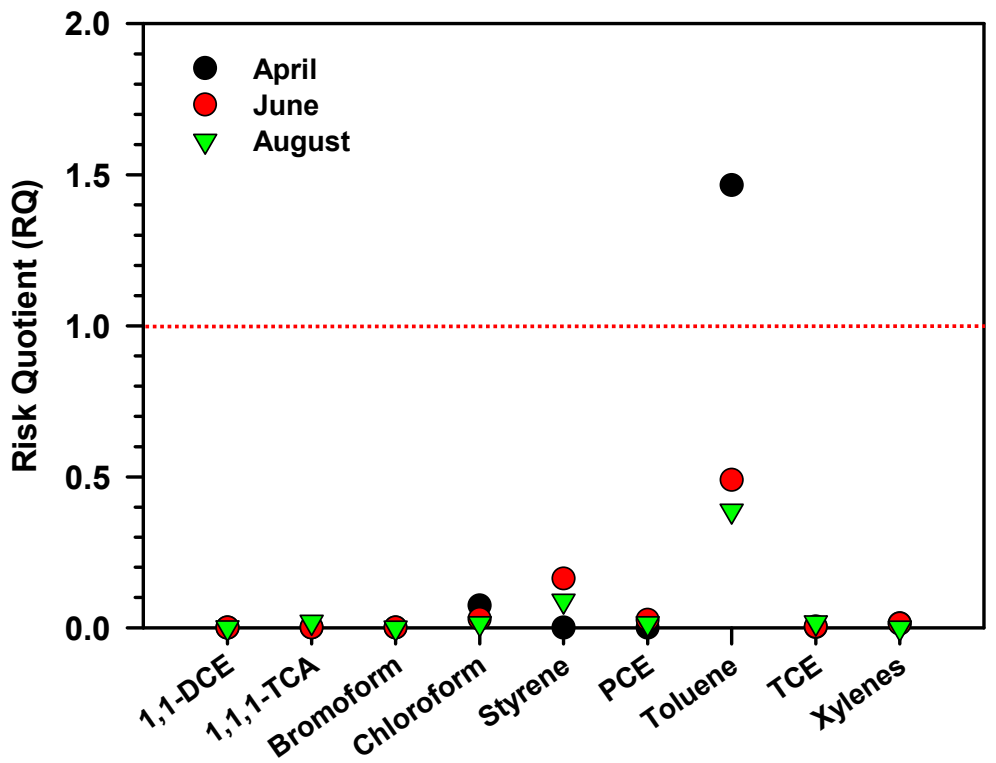

Figure 6. Risk quotients calculated for VOC concentrations in tributaries of the Han River basin.

Due to their airborne characteristics and well-known hazards, including cancer risk and non-cancerous effects, previous monitoring studies of VOCs have focused on human health risks [55-59], while very limited information is available for ecological risks [18,55], which warrant further study.

\section{Conclusions}

A total of 11 VOCs were detected at 36 sites along tributaries of the Han River basin, the largest drinking water source in South Korea. Chloroform was the most abundant 
compound, followed by TCE, showing that halocarbons accounted for $94 \%$ of total VOCs. These two substances had their highest concentrations in industrial areas. Chloroform correlated positively with TCE and xylenes, whereas TCE correlated positively with PCE. TCE exhibited a significant positive relationship with the watersheds of Imjin-Hantan River, Han River mainstream, and Anseong Stream, whereas chloroform had a strong positive relationship with the watersheds of Bukhan and Namhan rivers. There were no significant temporal differences in VOC concentrations obtained every other month from spring to summer. This may be attributed to continuous discharge from WWTPs upstream of the watershed. Despite containing similar VOC types, VOC concentrations and detection frequencies were higher in industrial areas than in urban areas. In addition, the STPs and industrial WWTPs are important sources of these VOCs, especially of halocarbons, to the tributaries. Surface waters are vulnerable to many contaminants from one or more sources located in the upstream watershed but have the ability to dilute such contaminants to a certain extent, thereby reducing their concentrations and mitigating their impacts. For example, as shown in the results from sites N-2, B-5, and H-7, significantly lower VOC concentrations were detected with increasing distance from the STPs. This study demonstrates that the ecological risks of most VOCs (except toluene) at their current concentrations are negligible. Continuous monitoring and further ecotoxicity studies of Korean aquatic species are necessary to further refine the findings. Scientifically, our findings could guide future research in other similar urban settings in South Korea and in many other countries, given that understanding pollutant behaviors and characteristics is essential to ensure water security in such areas. Additionally, considering the relatively high incidence of VOCs and the potential ecological risks they pose, the results obtained in this study would serve as an important data source for the determination of the environmental impact of these pollutants in future environmental monitoring and ecotoxicity studies of domestic aquatic species. In particular, to overcome the limitations of the results of this study, sufficient monitoring to confirm seasonal changes in VOC concentration and observation of the changes in VOC concentration for each process of WWTPs and STPs, which were identified as main pollutants, are required.

Supplementary Materials: The following are available online at https:/ / www.mdpi.com/article/ 10.3390/w13182568/s1. Figure S1: Spatial trends for cumulative VOC concentrations at different sites; Table S1: Physical and chemical properties of VOCs; Table S2: Water quality data measured at the sampling sites; Table S3: Purge-and-trap chromatography/mass spectrometry analytical conditions and parameters; Table S4: Measured VOC concentrations during the sampling periods; Table S5: Water quality guidelines for VOCs; Table S6: ANOVA analysis of VOC concentration by sampling time and site.

Author Contributions: Conceptualization, J.K.I. and Y.-M.L.; Methodology, H.R.N.; Software, Y.S.K. and S.K.; Validation, H.R.N. and Y.S.K.; Formal analysis, H.R.N. and Y.S.K.; Investigation, H.R.N. and Y.S.K.; Resources, S.J.Y.; Data curation, S.J.Y., H.R.N., Y.S.K., and S.K.; Writing-original draft preparation, J.K.I. and Y.-M.L.; Writing-review and editing, J.K.I., S.J.Y., Y.-M.L., S.K., and Y.S.K.; Visualization, Y.S.K.; Supervision, Y.-M.L. and S.J.Y.; Project administration, S.J.Y.; Funding acquisition, H.R.N. All authors have read and agreed to the published version of the manuscript.

Funding: This research was supported by the National Institute of Environmental Research (NIER) [grant number NIER-2019-01-01-065], funded by the Ministry of Environment (MOE) and Environmental Fundamental Data Examination Project of Han River Basin Management Committee of the Republic of Korea.

Institutional Review Board Statement: Not applicable.

Informed Consent Statement: Not applicable.

Data Availability Statement: Not applicable.

Conflicts of Interest: The authors declare no conflict of interest. 


\section{References}

1. Dewulf, J.; Van Langenhove, H. Anthropogenic volatile organic compounds in ambient air and natural waters: A review on recent developments of analytical methodology, performance and interpretation of field measurements. J. Chromatogr. A 1999, 843, 163-177. [CrossRef]

2. Lopes, T.J.; Dionne, S.G. A Review of Semivolatile and Volatile Organic Compounds in Highway Runoff and Urban Stormwater; US Department of the Interior, US Geological Survey: Reston, VI, USA, 1998; Volume 98.

3. Guenther, A. Seasonal and spatial variations in natural volatile organic compound emissions. Ecol. Appl. 1997, 7, 34-45. [CrossRef]

4. Huang, B.; Lei, C.; Wei, C.; Zeng, G. Chlorinated volatile organic compounds (Cl-VOCs) in environment-sources, potential human health impacts, and current remediation technologies. Environ. Int. 2014, 71, 118-138. [CrossRef]

5. Mellouki, A.; Wallington, T.; Chen, J. Atmospheric chemistry of oxygenated volatile organic compounds: Impacts on air quality and climate. Chem. Rev. 2015, 115, 3984-4014. [CrossRef] [PubMed]

6. Cao, F.; Qin, P.; Lu, S.; He, Q.; Wu, F.; Sun, H.; Wang, L.; Li, L. Measurement of volatile organic compounds and associated risk assessments through ingestion and dermal routes in Dongjiang Lake, China. Ecotox. Environ. Safe 2018, 165, 645-653. [CrossRef] [PubMed]

7. Chameides, W.; Lindsay, R.; Richardson, J.; Kiang, C. The role of biogenic hydrocarbons in urban photochemical smog: Atlanta as a case study. Science 1988, 241, 1473-1475. [CrossRef] [PubMed]

8. Liu, Y.; Shao, M.; Fu, L.; Lu, S.; Zeng, L.; Tang, D. Source profiles of volatile organic compounds (VOCs) measured in China: Part I. Atmos. Environ. 2008, 42, 6247-6260. [CrossRef]

9. Li, A.J.; Pal, V.K.; Kannan, K.A. review of environmental occurrence, toxicity, biotransformation and biomonitoring of volatile organic compounds. Environ. Chem. Ecotox. 2021, 3, 91-116.

10. Koppmann, R. Volatile Organic Compounds in the Atmosphere; John Wiley \& Sons: Hoboken, NJ, USA, 2008.

11. Kim, K.-H.; Ho, D.X.; Park, C.G.; Ma, C.-J.; Pandey, S.K.; Lee, S.C.; Jeong, H.J.; Lee, S.H. Volatile organic compounds in ambient air at four residential locations in Seoul, Korea. Environ. Eng. Sci. 2012, 29, 875-889. [CrossRef]

12. Kim, M.-J.; Seo, Y.-K.; Kim, J.-H.; Baek, S.-O. Impact of industrial activities on atmospheric volatile organic compounds in Sihwa-Banwol, the largest industrial area in South Korea. Environ. Sci. Pollut. Res. 2020, 27, 28912-28930. [CrossRef] [PubMed]

13. Kim, S.-J.; Kwon, H.-O.; Lee, M.-I.; Seo, Y.; Choi, S.-D. Spatial and temporal variations of volatile organic compounds using passive air samplers in the multi-industrial city of Ulsan, Korea. Environ. Sci. Pollut. Res. 2019, 26, 5831-5841. [CrossRef] [PubMed]

14. Kim, S.-Y.; Kim, J.-C.; Park, C.-R.; Son, Y.-S. Emission characteristics of biogenic volatile organic compounds from representative plant species of the Korean peninsula-Focused on aldehydes. Atmos. Res. 2020, 236, 104840. [CrossRef]

15. Nguyen, H.T.; Kim, K.-H.; Kim, M.-Y. Volatile organic compounds at an urban monitoring station in Korea. J. Hazard. Mater. 2009, 161, 163-174. [CrossRef] [PubMed]

16. Shin, H.; Roh, S.; Kim, J.; Lee, S.; Kim, Y. Temporal variation of volatile organic compounds and their major emission sources in Seoul, Korea. Environ. Sci. Pollut. Res. 2013, 20, 8717-8728. [CrossRef]

17. Simpson, I.J.; Blake, D.R.; Blake, N.J.; Meinardi, S.; Barletta, B.; Hughes, S.C.; Fleming, L.T.; Crawford, J.H.; Diskin, G.S.; Emmons, L.K. Characterization, sources and reactivity of volatile organic compounds (VOCs) in Seoul and surrounding regions during KORUS-AQ. Elem. Sci. Anthrop. 2020, 8, 37. [CrossRef]

18. Cho, E.; Khim, J.; Chung, S.; Seo, D.; Son, Y. Occurrence of micropollutants in four major rivers in Korea. Sci. Total Environ. 2014, 491, 138-147. [CrossRef]

19. Nikolaou, A.D.; Golfinopoulos, S.K.; Kostopoulou, M.N.; Kolokythas, G.A.; Lekkas, T.D. Determination of volatile organic compounds in surface waters and treated wastewater in Greece. Water Res. 2002, 36, 2883-2890. [CrossRef]

20. Squillace, P.J.; Scott, J.C.; Moran, M.J.; Nolan, B.; Kolpin, D.W. VOCs, pesticides, nitrate, and their mixtures in groundwater used for drinking water in the United States. Environ. Sci. Technol. 2002, 36, 1923-1930. [CrossRef]

21. Maslia, M.L.; Aral, M.M.; Ruckart, P.Z.; Bove, F.J. Reconstructing historical VOC concentrations in drinking water for epidemiological studies at a US Military base: Summary of results. Water 2016, 8, 449. [CrossRef] [PubMed]

22. Wu, B.-Z.; Feng, T.-Z.; Sree, U.; Chiu, K.-H.; Lo, J.-G. Sampling and analysis of volatile organics emitted from wastewater treatment plant and drain system of an industrial science park. Anal. Chim. Acta 2006, 576, 100-111. [CrossRef]

23. Martí, N.; Aguado, D.; Segovia-Martínez, L.; Bouzas, A.; Seco, A. Occurrence of priority pollutants in WWTP effluents and Mediterranean coastal waters of Spain. Mar. Pollut. Bul. 2011, 62, 615-625. [CrossRef] [PubMed]

24. Safarova, V.; Sapelnikova, S.; Djazhenko, E.; Teplova, G.; Shajdulina, G.; Kudasheva, F.K. Gas chromatography-mass spectrometry with headspace for the analysis of volatile organic compounds in waste water. J. Chromatogr. B 2004, 800, 325-330. [CrossRef]

25. Fatone, F.; Di Fabio, S.; Bolzonella, D.; Cecchi, F. Fate of aromatic hydrocarbons in Italian municipal wastewater systems: An overview of wastewater treatment using conventional activated-sludge processes (CASP) and membrane bioreactors (MBRs). Water Res. 2011, 45, 93-104. [CrossRef] [PubMed]

26. Pecoraino, G.; Scalici, L.; Avellone, G.; Ceraulo, L.; Favara, R.; Candela, E.G.; Provenzano, M.C.; Scaletta, C. Distribution of volatile organic compounds in Sicilian groundwaters analysed by head space-solid phase micro extraction coupled with gas chromatography mass spectrometry (SPME/GC/MS). Water Res. 2008, 42, 3563-3577. [CrossRef]

27. Al-Mudhaf, H.F.; Alsharifi, F.A.; Abu-Shady, A.-S.I. A survey of organic contaminants in household and bottled drinking waters in Kuwait. Sci. Total Environ. 2009, 407, 1658-1668. [CrossRef] [PubMed] 
28. Balaban, N.; Yankelzon, I.; Adar, E.; Gelman, F.; Ronen, Z.; Bernstein, A. The spatial distribution of the microbial community in a contaminated aquitard below an industrial zone. Water 2019, 11, 2128. [CrossRef]

29. Kong, L.; Kadokami, K.; Wang, S.; Duong, H.T.; Chau, H.T.C. Monitoring of 1300 organic micro-pollutants in surface waters from Tianjin, North China. Chemosphere 2015, 122, 125-130. [CrossRef] [PubMed]

30. Chen, Y.; Zhao, K.; Wu, Y.; Gao, S.; Cao, W.; Bo, Y.; Shang, Z.; Wu, J.; Zhou, F. Spatio-temporal patterns and source identification of water pollution in Lake Taihu (China). Water 2016, 8, 86. [CrossRef]

31. Liang, Z.; Wang, J.; Zhang, Y.; Han, C.; Ma, S.; Chen, J.; Li, G.; An, T. Removal of volatile organic compounds (VOCs) emitted from a textile dyeing wastewater treatment plant and the attenuation of respiratory health risks using a pilot-scale biofilter. J. Clean. Prod. 2020, 253, 120019. [CrossRef]

32. Zhou, L.J.; Rong, Z.Y.; Gu, W.; Fan, D.L.; Liu, J.N.; Shi, L.L.; Xu, Y.H.; Liu, Z.Y. Integrated fate assessment of aromatic amines in aerobic sewage treatment plants. Environ. Monit. Assess. 2020, 192, 278. [CrossRef]

33. Im, J.K.; Yu, S.J.; Kim, S.; Kim, S.H.; Noh, H.R.; Kim, M.K. Occurrence, Potential Sources, and Risk Assessment of Volatile Organic Compounds in the Han River Basin, South Korea. Int. J. Environ. Res. Public Health 2021, 18, 3727. [CrossRef]

34. Im, J.-K.; Cho, Y.-C.; Noh, H.-R.; Yu, S.-J. Geographical Distribution and Risk Assessment of Volatile Organic Compounds in Tributaries of the Han River Watershed. Agronomy 2021, 11, 956. [CrossRef]

35. National Institute of Environmental Research (NIER). A Study on Selection of Priority Management Compounds for Water Quality and Aquatic Ecosystems; National Institute of Environmental Research (NIER): Incheon, Korea, 2010.

36. Rice, E.W.; Baird, R.B.; Eaton, A.D. (Eds.) Standard Methods for the Examination of Water and Wastewater; American Public Health Association (APHA): Washington, DC, USA, 2005.

37. Chen, B.; Westerhoff, P. Predicting disinfection by-product formation potential in water. Water Res. 2010, 44, 3755-3762. [CrossRef]

38. Qin, P.; Cao, F.; Lu, S.; Li, L.; Guo, X.; Zhao, B.; Wan, Z.; Bi, B. Occurrence and health risk assessment of volatile organic compounds in the surface water of Poyang Lake in March 2017. RSC Adv. 2019, 9, 22609-22617. [CrossRef]

39. IARC. Trichloroethylene, Tetrachloroethylene, and Some Other Chlorinated Agents; IARC: Lyon, France, 2014 ; Volume 106.

40. ATSDR. Toxicological Profile for Trichloroethylene (TCE); ATSDR: Atlanta, GA, USA, 2019.

41. Shukla, A.K.; Upadhyay, S.N.; Dubey, S.K. Current trends in trichloroethylene biodegradation: A review. Crit. Rev. Biotechnol. 2014, 34, 101-114. [CrossRef]

42. Bianchi, A.P.; Varney, M.S. Volatile organic compounds in the surface waters of a British estuary. Part 2. Fate processes. Water Res. 1998, 32, 371-379. [CrossRef]

43. Padalkar, A.V.; Kumar, R. Removal mechanisms of volatile organic compounds (VOCs) from effluent of common effluent treatment plant (CETP). Chemosphere 2018, 199, 569-584. [CrossRef] [PubMed]

44. Mullaugh, K.M.; Hamilton, J.M.; Avery, G.B.; Felix, J.D.; Mead, R.N.; Willey, J.D.; Kieber, R.J. Temporal and spatial variability of trace volatile organic compounds in rainwater. Chemosphere 2015, 134, 203-209. [CrossRef] [PubMed]

45. Li, H.; Wang, Y.; Liu, F.; Tong, L.; Li, K.; Yang, H.; Zhang, L. Volatile organic compounds in stormwater from a community of Beijing, China. Environ. Pollut. 2018, 239, 554-561. [CrossRef] [PubMed]

46. An, J.; Zhu, B.; Wang, H.; Li, Y.; Lin, X.; Yang, H. Characteristics and source apportionment of VOCs measured in an industrial area of Nanjing, Yangtze River Delta, China. Atmos. Environ. 2014, 97, 206-214. [CrossRef]

47. Hsieh, L.-T.; Yang, H.-H.; Chen, H.-W. Ambient BTEX and MTBE in the neighborhoods of different industrial parks in Southern Taiwan. J. Hazard. Mater. 2006, 128, 106-115. [CrossRef]

48. Li, Q.; Zhang, H.; Guo, S.; Fu, K.; Liao, L.; Xu, Y.; Cheng, S. Groundwater pollution source apportionment using principal component analysis in a multiple land-use area in southwestern China. Environ. Sci. Pollut. Res. 2020, 27, 9000-9011. [CrossRef]

49. Binda, G.; Pozzi, A.; Michetti, A.M.; Noble, P.J.; Rosen, M.R. Towards the understanding of hydrogeochemical seismic responses in karst aquifers: A retrospective meta-analysis focused on the apennines (Italy). Minerals 2020, 10, 1058. [CrossRef]

50. Huang, Y.; Sui, Q.; Lyu, S.; Wang, J.; Huang, S.; Zhao, W.; Wang, B.; Xu, D.; Kong, M.; Zhang, Y. Tracking emission sources of PAHs in a region with pollution-intensive industries, Taihu Basin: From potential pollution sources to surface water. Environ. Pollut. 2020, 264, 114674. [CrossRef]

51. Wang, J.; Sui, Q.; Lyu, S.; Huang, Y.; Huang, S.; Wang, B.; Xu, D.; Zhao, W.; Kong, M.; Zhang, Y. Source apportionment of phenolic compounds based on a simultaneous monitoring of surface water and emission sources: A case study in a typical region adjacent to Taihu Lake watershed. Sci. Total Environ. 2020, 722, 137946. [CrossRef]

52. McGrane, S.J. Impacts of urbanisation on hydrological and water quality dynamics, and urban water management: A review. Hydrol. Sci. J. 2016, 61, 2295-2311. [CrossRef]

53. Yu, S.; Lee, P.-K.; Yun, S.-T.; Hwang, S.-I.; Chae, G. Comparison of volatile organic compounds in stormwater and groundwater in Seoul metropolitan city, South Korea. Environ. Earth Sci. 2017, 76, 338. [CrossRef]

54. An, Y.-J.; Nam, S.-H.; Lee, J.-K. Domestic test species for aquatic toxicity assessment in Korea. Korean J. Ecol. Environ. 2007, 40, $1-13$.

55. Chen, X.; Luo, Q.; Wang, D.; Gao, J.; Wei, Z.; Wang, Z.; Zhou, H.; Mazumder, A. Simultaneous assessments of occurrence, ecological, human health, and organoleptic hazards for 77 VOCs in typical drinking water sources from 5 major river basins, China. Environ. Pollut. 2015, 206, 64-72. [CrossRef] 
56. Kumar, A.; Singh, D.; Kumar, K.; Singh, B.B.; Jain, V.K. Distribution of VOCs in urban and rural atmospheres of subtropical India: Temporal variation, source attribution, ratios, OFP and risk assessment. Sci. Total Environ. 2018, 613, 492-501. [CrossRef] [PubMed]

57. Xiong, Y.; Bari, M.A.; Xing, Z.; Du, K. Ambient volatile organic compounds (VOCs) in two coastal cities in western Canada: Spatiotemporal variation, source apportionment, and health risk assessment. Sci. Total Environ. 2020, 706, 135970. [CrossRef] [PubMed]

58. Zhang, Z.; Yan, X.; Gao, F.; Thai, P.; Wang, H.; Chen, D.; Zhou, L.; Gong, D.; Li, Q.; Morawska, L. Emission and health risk assessment of volatile organic compounds in various processes of a petroleum refinery in the Pearl River Delta, China. Environ. Pollut. 2018, 238, 452-461. [CrossRef] [PubMed]

59. Zheng, H.; Kong, S.; Yan, Y.; Chen, N.; Yao, L.; Liu, X.; Wu, F.; Cheng, Y.; Niu, Z.; Zheng, S. Compositions, sources and health risks of ambient volatile organic compounds (VOCs) at a petrochemical industrial park along the Yangtze River. Sci. Total Environ. 2020, 703, 135505. [CrossRef] [PubMed] 